\title{
Lifestyle interventions to maternal weight loss after birth: a systematic review
}

Pernille Kjaergaard Christiansen ${ }^{1,2,3,4^{*}}$, Mette Maria Skjøth ${ }^{1,2,4}$, Mette Juel Rothmann ${ }^{2,4,5,6,7}$, Christina Anne Vinter ${ }^{7,8}$ (D) Ronald Francis Lamont ${ }^{8,9,10}$ and Eva Draborg ${ }^{1}$

\begin{abstract}
Background: Over the past decades, there has been an increase in overweight and obesity in women of childbearing age, as well as the general population. Overweight and obesity are related to a later, increased risk of type 2 diabetes and cardiovascular diseases. Increasing weight between pregnancies has a negative impact on the development of the fetus in a subsequent pregnancy. It is also related to long-term obesity and overweight for the woman. Accordingly, weight control in women of the childbearing age is important for both women and their offspring. Information and communication technology (ICT) has become an integrated part of many peoples' lives, and it has the potential to prevent disease. In this systematic review, we summarize the evidence from randomized controlled trials to compare effects of different ICT-based interventions to support postpartum women to achieve weight loss.
\end{abstract}

Methods: A systematic search was performed in PubMed, Embase, Psyclnfo, CINAHL, Web of Science, Scopus, and Cochrane, searching on terms, such as postpartum, weight loss, telemedicine, and randomized controlled trials. Two independent researchers undertook study selection and data extraction. Results were reported narratively. The systematic review only included studies that were randomized controlled trials.

Results: Eight studies were included in the systematic review. All of them were characterized by applying one or more ICT components to assist postpartum women in weight control, and had weight loss as an outcome measure. A significant difference was found in weight loss between control group and intervention group in the majority of the studies. However, five of the studies had a relatively short follow-up period (40 days to 16 weeks), six of the studies had a relatively small sample size (18 to 66 women), and half of the studies indicated challenges with adherence to the interventions over time.

Conclusion: ICT-based interventions can support postpartum women to achieve a healthy lifestyle and weight control. Future studies should focus on larger sample sizes, longer follow-up periods, and adherence to the interventions.

Systematic review registration: PROSPERO CRD42018080731

Keywords: Healthy Life Style, Information and Communication Technology, Postpartum, Intervention, Systematic Review, Weight Control

\footnotetext{
* Correspondence: pchristiansen@health.sdu.dk

'Department of Public Health, University of Southern Denmark, Odense,

Denmark

${ }^{2}$ Centre for Innovative Medical Technology, Odense University Hospital,

Odense, Denmark

Full list of author information is available at the end of the article
}

(c) The Author(s). 2019 Open Access This article is distributed under the terms of the Creative Commons Attribution 4.0 International License (http://creativecommons.org/licenses/by/4.0/), which permits unrestricted use, distribution, and reproduction in any medium, provided you give appropriate credit to the original author(s) and the source, provide a link to the Creative Commons license, and indicate if changes were made. The Creative Commons Public Domain Dedication waiver (http://creativecommons.org/publicdomain/zero/1.0/) applies to the data made available in this article, unless otherwise stated. 


\section{Key message}

Maternal obesity is an independent risk factor for adverse maternal and fetal outcomes including gestational diabetes and childhood obesity. ICT-based interventions can support weight loss among postpartum women. Future studies should focus on longer follow-up period, larger sample sizes, and adherence to the interventions.

\section{Background}

Over the past decades, there has been an increase in women of childbearing age as well as in the general population, who are either overweight or obese [1]. The amount of self-reported overweight or obese women in Denmark has increased from $24.5 \%$ in 2000 to $27.8 \%$ in 2017 and in the USA from 27.9 in 2001 to $28.9 \%$ in 2016 [2]. Obesity has a significantly negative impact on fertility, adverse pregnancy outcomes such as gestational diabetes mellitus (GDM) and preeclampsia, and birth outcomes [3]. Obesity compromises the health of the mother and the offspring [4] and is related to increased risk of type 2 diabetes (T2DM) and cardiovascular disease in the mother in later life [5]. 40.9\% of women diagnosed with GDM are estimated to develop T2DM within 7 years of their pregnancy [6]. Increasing weight between pregnancies has a negative impact on the development of the fetus in a subsequent pregnancy $[7,8]$. It is also related to being obese and overweight long term. Accordingly, weight control among women of childbearing age is important for both women and their offspring.

Several studies indicate that $>50 \%$ of all pregnant women with a body mass index (BMI) $>25 \mathrm{~kg} / \mathrm{m}^{2}$ gain more weight during pregnancy than recommended by the Institute of Medicine (IOM) [9]. The IOM recommends that underweight women should gain between 12.5 and $18 \mathrm{~kg}$ during pregnancy, women with a normal BMI should gain between 11.5 and $16 \mathrm{~kg}$, those that are overweight should gain 7 to $11.5 \mathrm{~kg}$, and those that are obese should gain 5 to $9 \mathrm{~kg}$ [10]. Gestational weight gain (GWG) exceeding the IOM recommendations is associated with postpartum weight retention [11, 12], which puts the woman at higher risk of developing gestational diabetes mellitus (GDM) in a subsequent pregnancy [4]. In the postpartum period, most women lose some of the weight gained during pregnancy, but in many cases, the women will end up with a higher BMI compared to their pre-pregnancy BMI [7].

Information and Communication Technology (ICT) has become an integral part of many individuals' everyday lives and has the potential to support prevention of disease and improve lives [13]. ICT can be defined as "ICT refers to technologies that provide access to information through telecommunications. It is similar to Information Technology (IT), but focuses primarily on communication technologies. This includes the Internet, wireless networks, cell phones, and other communication mediums." [14]. Women of childbearing age use ICT to gain information, including health-related issues during pregnancy, and child development [15]. According to Danish data, $94 \%$ of Danish families own a cellphone, and $84 \%$ percent own a smartphone [16]. ICT can improve or assist the services provided by the healthcare sector through more customized, efficient, and frequent communication, compared to standard treatments, where communication is face to face or by telephone [17]. Between pregnancies, there is a window of opportunity to focus on weight loss through lifestyle interventions. Starting a family is life changing, and this period can be used to promote a healthy lifestyle and weight control $[18,19]$. Recently, there has been an increased interest in the use of ICT to support weight control in relation to pregnancy, and a variety of interventions have been introduced to support weight loss among women in the postpartum period [20]. The objective of this systematic review is to summarize the evidence from randomized controlled trials (RCTs) to compare the effects of different ICT-based interventions to support postpartum women to achieve weight loss.

\section{Methods}

This present study uses a systematic review methodology [21]. The paper is based on the PRISMA statement [22] together with a protocol that has been registered in PROSPERO (CRD42018080731). The synthesis is narrative, as the study designs and samples vary.

\section{Data sources}

A systematic search was performed in PubMed, Embase, PsycInfo, CINAHL, Web of Science, Scopus, and Cochrane. The first author (PKC), assisted by a research librarian, generated a literature search strategy and searched the databases. The literature searches were carried out from May 2017 to February 2018. On the 27th of February 2018, a final search update was made in all databases.

\section{Search strategy}

The search strategy aimed to identify published studies available in full text. A block search strategy, with relevant words, "postpartum," "weight loss," "telemedicine," and "randomized controlled trials" containing both $\mathrm{MeSH}$ terms/keywords, and free text, was used together with the terms (AND/OR/NOT). No language or time restrictions were made. RCT filters were applied in PubMed and in Embase, and a filter excluding animal studies was applied in the search in PubMed. The search string is presented in Additional file 1. It was modified for each database. References identified from the search were imported directly into the reference database 
(EndNote) and later to Covidence. Further publications were sought through the identified articles' list of references.

\section{Inclusion/exclusion criteria for the study selection}

The PICO (Population, Intervention [or exposure], Comparison, and Outcome) framework was used to clarify the search [23].

Population: Postpartum women, $\geq 18$ years of age participating in an RCT on postpartum weight control. We excluded studies specifically focusing on women with GDM.

Intervention: An ICT-based intervention supporting postpartum women in a healthy lifestyle designed for weight control.

Comparison: The intervention group was compared to a control group that received a standard care in the respective communities, where they live.

Outcome: Weight loss at the end of the intervention period.

Only original publications from peer-reviewed journals about postpartum women and weight loss that were RCTs testing an ICT intervention, and fulfilled the PICO framework, were considered for inclusion in the systematic review. Studies that focused on pregnancy per se were not included. The search, selection, and assessment process were performed in four steps in keeping with the PRISMA flow diagram shown in Fig. 1. The steps were (i) systematic literature search, (ii) removal of duplicates, (iii) identification of potentially relevant articles based on the title and abstract, and (iv) full-text screening. The first author assisted by a librarian performed the search string for the electronic search. Title and abstract were screened in Covidence, which identified a list of duplicates, that were manually checked by the 1st author. A total of 575 articles were removed due to duplicates. First author screened titles and abstracts, and first and second authors read the full text of the remaining articles separately for inclusion or exclusion in the review. Disagreements between the reviewers were resolved by consensus.

\section{Data extraction and quality assessment}

To ensure reliability, and determine the risk of bias in each study, a quality assessment, using Cochrane's tool

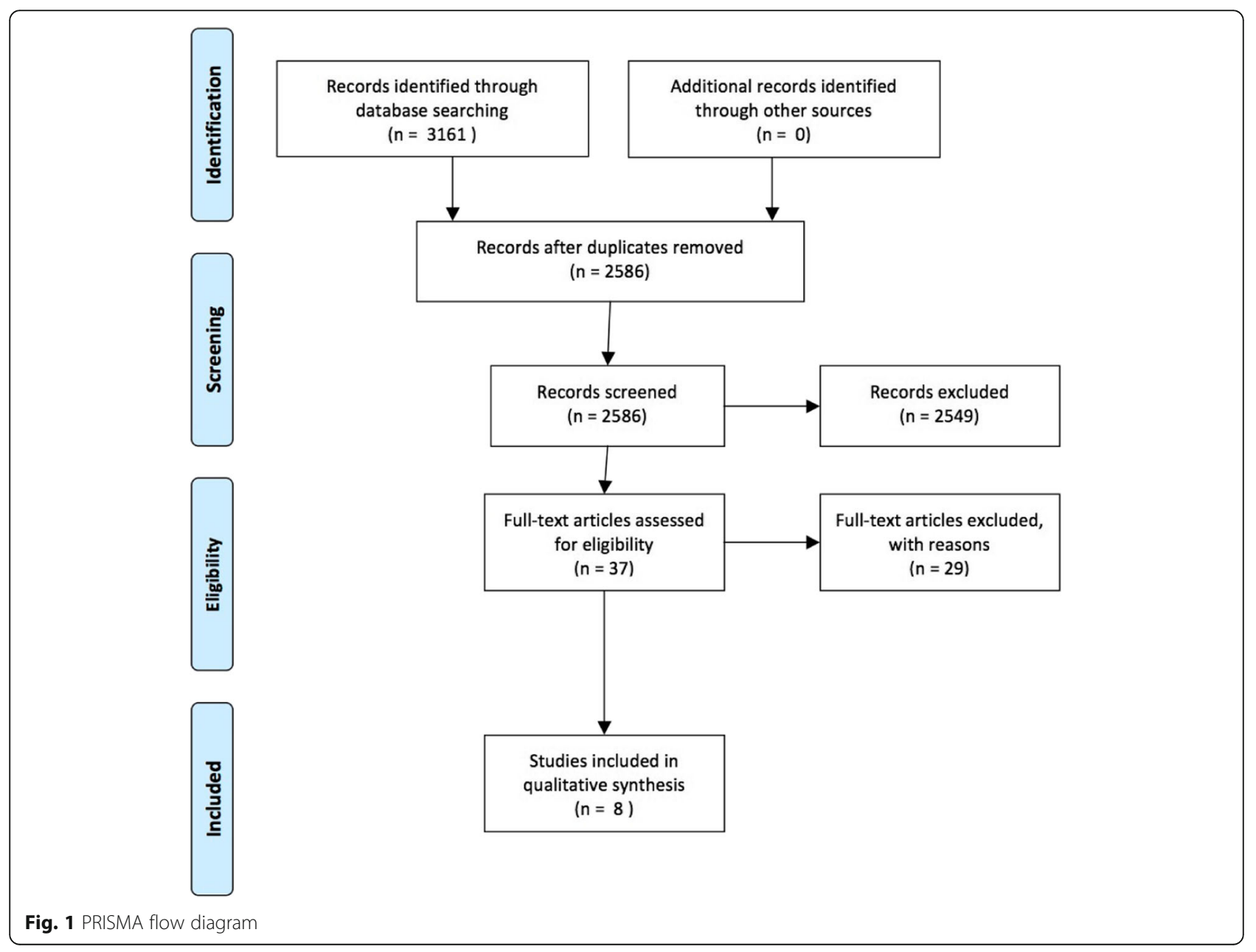


for risk of bias in randomized trials, was applied [24]. The checklist comprises seven areas: (i) random sequence generation, (ii) allocation concealment, (iii) blinding of participants and personnel, (iv) blinding of outcome assessment, (v) incomplete outcome data, (vi) selective reporting, and (vii) other bias. As Cochrane's tool for risk of bias is applied, there are no overall evaluations of each study [24]. An overview of the risk of bias in each study, and scores, is presented in Table 1. The quality of each of the seven criterions were assessed separately and entered in the table with symbols. A "low risk of bias" was estimated, if all or most of the criteria are met $(+)$, "unclear risk of bias" if some of the criteria are met (?), and "high risk of bias" if only few or none of the criteria are met (-). First and second authors reviewed the studies independently accordingly to the quality checklist. Disagreements between the reviewers were resolved by consensus.

\section{Results}

The Prisma Flow Chart summarizes the selection of articles found in the systematic review (Fig. 1), and 3161 articles were found through the search in the seven databases. Once duplicates were removed, 2586 articles remained. After screening the title and abstract, based on the criteria from the PICO, 37 articles remained, and after full-text screening, eight studies were left for inclusion in the systematic review [19, 25-31]. Articles excluded in the full-text screening were excluded due to missing ICT in the intervention, or the sample, study design, or outcome did not fulfill the criteria listed in the PICO.

Descriptive information on the included studies is presented in Table 2 at the end of the article and illustrates a list of selected characteristics of each study. The studies were published between 2011 and 2017. Six of the studies were conducted in the USA [19, 25-27, 30, 31], one in Iran [29], and one in Japan [28]. The time span from collecting data to publication varied between 1 year [29] and 4 years [30]. One study did not indicate when data was collected [28]. Although the search was designed to identify postpartum women, one study also included pregnant women but the main focus was on the postpartum period [26]. Baseline characteristics varied between the studies. All studies focused on postpartum women; however, one study did include pregnant women as well [20]. Five studies focused on overweight or obese postpartum women, or women who had exceeded the IOM's recommendations for weight gain during pregnancy $[19,25-27,31]$, while two focused on inactive postpartum women $[29,30]$, and one study on postpartum women with a BMI $24.9 \pm 3.4 \mathrm{~kg} / \mathrm{m}^{2}$ [28]. Minority groups were also the main focus in some of the American studies (postpartum women on low income) $[19,27]$ or postpartum women from ethnic minority groups $[25,26]$. Seven studies used weight loss $(\mathrm{kg})$ as an outcome $[17,25-29,31]$, while one study only examined minutes of moderate to vigorous physical activity (MVPA) [30] as a proxy to weight loss, so the study was included in the systematic review. Five of the studies had a relatively short follow-up period of 40 days to 16 weeks [25, 27-29, 31], while three studies had a follow-up period between 12 and 20 months [19, 26, 30]. A large variation was found between sample sizes of the studies. Six studies had a relatively small sample size, between 18 and 66 participants $[26-29,31]$, while two studies had larger sample sizes of 311 and 371 participants [19, 30]. Drop out was between 5.5\% [25] and 23.73\% [19]. Seven of the studies used ICT as a tool to support counseling $[19,25-27,29-31]$, while only one study used ICT alone as an intervention [28]. The attrition rate in the eight studies varied from $5.6 \%$ [25] to $23.7 \%$ [19]. Five studies applied Intention to Treat (ITT) analysis, which indicated a low risk of bias $[19,25-27,30]$. One study used

Table 1 Evaluation of Cochran's six sources of bias in studies from 2012 to 2017 of weight loss among women who have given birth

\begin{tabular}{|c|c|c|c|c|c|c|c|}
\hline & $\begin{array}{l}\text { Random Sequence } \\
\text { generation }\end{array}$ & $\begin{array}{l}\text { Allocation } \\
\text { concealment }\end{array}$ & $\begin{array}{l}\text { Blinding of participants } \\
\text { and personnel }\end{array}$ & $\begin{array}{l}\text { Blinding of outcome } \\
\text { assessment }\end{array}$ & $\begin{array}{l}\text { Incomplete } \\
\text { outcome data }\end{array}$ & $\begin{array}{l}\text { Selective } \\
\text { reporting }\end{array}$ & $\begin{array}{l}\text { Other } \\
\text { bias }\end{array}$ \\
\hline Phelan et al. [19] & $(+)$ & $(+)$ & $(+)$ & $(+)$ & $(+)$ & $(+)$ & $(+)$ \\
\hline Herring et al. [25] & $(+)$ & $(+)$ & (?) & (?) & $(+)$ & $(+)$ & $(+)$ \\
\hline Herring et al. [26] & $(+)$ & $(-)$ & (?) & $(-)$ & $(+)$ & $(+)$ & $(+)$ \\
\hline $\begin{array}{l}\text { Gilmore et al. } \\
\text { [27] }\end{array}$ & $(+)$ & $(-)$ & $(-)$ & $(-)$ & $(+)$ & $(+)$ & $(+)$ \\
\hline Tripette et al. [28] & $(+)$ & $(-)$ & $(-)$ & $(-)$ & (?) & $(+)$ & $(+)$ \\
\hline Maturi et al. [29] & $(+)$ & $(+)$ & (?) & $(-)$ & (?) & $(+)$ & $(+)$ \\
\hline $\begin{array}{l}\text { Albright et al. } \\
\text { [30] }\end{array}$ & $(+)$ & $(+)$ & (?) & $(+)$ & $(+)$ & $(+)$ & $(+)$ \\
\hline $\begin{array}{l}\text { Colleran and } \\
\text { Lovelady [31] }\end{array}$ & $(+)$ & $(+)$ & $(-)$ & $(-)$ & $(-)$ & $(+)$ & $(+)$ \\
\hline
\end{tabular}


Table 2 Study characteristics

\begin{tabular}{|c|c|c|c|c|c|c|}
\hline Reference & Author/year & Article & Setting & \multicolumn{3}{|l|}{ Sample } \\
\hline [19] & $\begin{array}{l}\text { Phelan et al. } \\
\text { (2017) }\end{array}$ & $\begin{array}{l}\text { Effect of an Internet-Based } \\
\text { Program on Weight Loss } \\
\text { for Low-income } \\
\text { postpartum women - A } \\
\text { Randomized Clinical Trial }\end{array}$ & California, USA & \multicolumn{3}{|c|}{$\begin{array}{l}\text { Postpartum women ( } 6 \text { weeks to } 12 \text { months } \\
\text { postpartum), BMl above } 25 \text {, or with a BMl } \\
22-24.9 \text {, but exceeding IOM recommendations } \\
\text { for GWG with more than } 4.5 \mathrm{~kg} \text {. Age } 18-40 \text {. } \\
\text { English or Spanish speaking, non-smoking, } \\
\text { owned a cell-phone, min. } 5 \text { th grade } \\
\text { education. }\end{array}$} \\
\hline [25] & $\begin{array}{l}\text { Herring et al. } \\
\text { (2014) }\end{array}$ & $\begin{array}{l}\text { Using Technology to } \\
\text { Promote Postpartum } \\
\text { Weight loss in Urban, Low- } \\
\text { Income Mothers: A Pilot } \\
\text { Randomized Controlled } \\
\text { Trial }\end{array}$ & Philadelphia, PA, USA. & \multicolumn{3}{|c|}{$\begin{array}{l}\text { Postpartum women, who delivered a singleton } \\
\text { within the last } 2 \text { to } 12 \text { months, min. } 18 \text { years old, } \\
\text { early pregnancy BMl greater than or equal to } 25, \\
\text { weight at enrolment that exceeded early } \\
\text { pregnancy weight by at least } 5 \mathrm{~kg} \text {. }\end{array}$} \\
\hline [26] & $\begin{array}{l}\text { Herring et al. } \\
\text { (2017) }\end{array}$ & $\begin{array}{l}\text { Intervening during and } \\
\text { after pregnancy to prevent } \\
\text { weight retention among } \\
\text { African American women }\end{array}$ & Philadelphia, PA, USA. & \multicolumn{3}{|c|}{$\begin{array}{l}\text { African American Women } \\
\text { (36\% overweight; } 64 \% \text { obese). }\end{array}$} \\
\hline [27] & $\begin{array}{l}\text { Gilmore et al. } \\
\text { (2017) }\end{array}$ & $\begin{array}{l}\text { Personalized Mobile Health } \\
\text { Intervention for Health and } \\
\text { Weight Loss in Postpartum } \\
\text { Women Receiving Women, } \\
\text { Infants, and Children } \\
\text { Benefit: A Randomized } \\
\text { Controlled Pilot Study }\end{array}$ & $\begin{array}{l}\text { Baton Rouge, } \\
\text { Louisiana, USA. }\end{array}$ & \multicolumn{3}{|c|}{$\begin{array}{l}\text { Postpartum women, who gave birth within the } \\
\text { past } 8 \text { weeks, no younger than } 18 \text { years old, } \\
\text { overweight or obese (BMI from } 25 \text { up to } 40 \text { ), } \\
\text { certified for WIC postpartum services, and English } \\
\text { speaking. }\end{array}$} \\
\hline [28] & $\begin{array}{l}\text { Tripette et al. } \\
\text { (2014) }\end{array}$ & $\begin{array}{l}\text { Home-Based Active Video } \\
\text { Games to Promote Weight } \\
\text { Loss during the Postpartum } \\
\text { Period }\end{array}$ & $\begin{array}{l}\text { Tokyo Metropolitan } \\
\text { Area, Japan }\end{array}$ & \multicolumn{3}{|c|}{$\begin{array}{l}\text { Postpartum women with a BMI } 24.5 \pm \\
3,4.3 \text { months to } 1 \text { year postpartum }\end{array}$} \\
\hline [29] & $\begin{array}{l}\text { Maturi et al. } \\
(2011)\end{array}$ & $\begin{array}{l}\text { Effect of physical activity } \\
\text { intervention based on a } \\
\text { pedometer on physical } \\
\text { activity level and } \\
\text { anthropometric measures } \\
\text { after childbirth: a } \\
\text { randomized controlled trial }\end{array}$ & Abadan, Iran & \multicolumn{3}{|c|}{$\begin{array}{l}\text { Postpartum women who had given birth } 6 \text { weeks } \\
\text { to } 12 \text { months prior }\end{array}$} \\
\hline [30] & $\begin{array}{l}\text { Albright et al. } \\
\text { (2014) }\end{array}$ & $\begin{array}{l}\text { Effectiveness of a 12-month } \\
\text { randomized clinical trial to } \\
\text { increase physical activity in } \\
\text { multi-ethnic postpartum } \\
\text { women: Results from } \\
\text { Hawaii's Nā Mikimiki Project }\end{array}$ & Hawaii, USA & \multicolumn{3}{|c|}{$\begin{array}{l}\text { Healthy, postpartum women, who were not } \\
\text { regularly active ( }<30 \text { min moderate to vigorous } \\
\text { physical activity/week); } 18-45 \text { years of age; BMls } \\
\text { from } 18.5 \text { to } 40 \text {; infants between } 2 \text { and } 12 \text { months. }\end{array}$} \\
\hline [31] & $\begin{array}{l}\text { Colleran and } \\
\text { Lovelady } \\
\text { (2012) }\end{array}$ & $\begin{array}{l}\text { Use of MyPyramid Menu } \\
\text { Planner for Moms in a } \\
\text { Weight-Loss Intervention } \\
\text { during Lactation }\end{array}$ & Minnesota, USA & \multicolumn{3}{|c|}{$\begin{array}{l}\text { Mothers between } 23 \text { and } 37 \text { years of age with } \\
\text { full-term ( } 37 \text { weeks) infants less than } 3 \text { weeks old, } \\
\text { self-reported postpartum body mass index (BMI; } \\
\text { calculated as } \mathrm{kg} / \mathrm{m} 2 \text { ) between } 25 \text { and } 30 \text {, fully } \\
\text { breastfeeding, } 3 \text { days a week of structured } \\
\text { physical activity for the past } 3 \text { months, cleared by } \\
\text { their physician to participate in exercise }\end{array}$} \\
\hline Reference & $\begin{array}{l}\text { Data gathering } \\
\text { (year) }\end{array}$ & Follow-up period & Outcome measure(s) & Sample Size & $\begin{array}{l}\text { Drop out/ } \\
\text { percentage }\end{array}$ & $\begin{array}{l}\text { Significant } \\
\text { change? }\end{array}$ \\
\hline [19] & $2011-2015$ & 12 months & $\begin{array}{l}\text { Weight loss, physical } \\
\text { activity and diet change }\end{array}$ & $N=371$ & 88 persons/23.72\% & Yes \\
\hline [25] & No information & 14 weeks & $\begin{array}{l}\text { Weight loss, physical } \\
\text { activity, and energy } \\
\text { intake }\end{array}$ & $N=18$ & 1 person/5.55\% & $\begin{array}{l}\text { Yes, weight loss } \\
\text { and energy intake. } \\
\text { No change in } \\
\text { physical activity }\end{array}$ \\
\hline [26] & 2013-2014 & 16-20 months & $\begin{array}{l}\text { Weight loss (percentage } \\
\text { of women who regain or } \\
\text { are below their early } \\
\text { pregnancy weight by } 6\end{array}$ & $N=66$ & 10 persons/15.15\% & $\begin{array}{l}\text { Yes, at } 6 \text { months } \\
\text { postpartum, but } \\
\text { not at } 12 \text { months } \\
\text { postpartum }\end{array}$ \\
\hline
\end{tabular}

12 months postpartum 
Table 2 Study characteristics (Continued)

\begin{tabular}{|c|c|c|c|c|c|c|}
\hline Reference & Author/year & Article & Setting & Sample & & \\
\hline [27] & No information & 16 weeks & $\begin{array}{l}\text { Weight loss, vital signs, } \\
\text { circumferences, body } \\
\text { composition }\end{array}$ & $N=40$ & 5 persons $/ 12.50 \%$ & $\begin{array}{l}\text { No, only within } \\
\text { high adherence } \\
\text { groups (body } \\
\text { weight and body } \\
\text { fat reduction) }\end{array}$ \\
\hline [28] & No information & 40 days & $\begin{array}{l}\text { Weight loss, improve } \\
\text { body composition }\end{array}$ & $N=34$ & 4 persons/11.75\% & Yes \\
\hline [29] & 2010 & 12 weeks & $\begin{array}{l}\text { Physical activity, } \\
\text { weight loss }\end{array}$ & $N=66$ & 4 persons $/ 6.06 \%$ & Yes \\
\hline [30] & 2008-2011 & 12 months & $\begin{array}{l}\text { Moderate-to-vigorous } \\
\text { physical activity/week }\end{array}$ & $N=311$ & 62 persons/19.94\% & $\begin{array}{l}\text { Yes, but only } \\
\text { among those with } \\
\text { low MVPA at } \\
\text { baseline. }\end{array}$ \\
\hline$[31]$ & 2008-2010 & 16 weeks & $\begin{array}{l}\text { Weight loss, energy } \\
\text { intake }\end{array}$ & $N=31$ & 4 persons/12.90\% & Yes \\
\hline Reference & $\begin{array}{l}\text { Adherence } \\
\text { issues }\end{array}$ & Published protocol? & Intention to treat (ITT) & ICT component(s) & $\begin{array}{l}\text { ICT alone or as a } \\
\text { supplement to } \\
\text { counseling? }\end{array}$ & Voucher/present \\
\hline [19] & $\begin{array}{l}\text { Yes, there is a } \\
\text { correlation } \\
\text { between } \\
\text { adherence and } \\
\text { results }\end{array}$ & Yes & Yes & $\begin{array}{l}\text { Website, text messages, } \\
\text { accelerometer }\end{array}$ & $\begin{array}{l}\text { ICT is a supplement } \\
\text { to counseling. }\end{array}$ & $\begin{array}{l}25 \text { dollars for } \\
\text { completing } \\
\text { baseline and } 6 \\
\text { months' } \\
\text { assessment, and } 50 \\
\text { dollars for the } 12 \\
\text { months' } \\
\text { assessment. }\end{array}$ \\
\hline [25] & $\begin{array}{l}\text { Yes, over time } \\
\text { there is an } \\
\text { issue with } \\
\text { adherence }\end{array}$ & Not mentioned & Yes & $\begin{array}{l}\text { Healthy } 4 \text { Baby, Daily text } \\
\text { messages, Bi-weekly } \\
\text { phone calls from a coach, } \\
\text { Training skills through } \\
\text { Facebook }\end{array}$ & $\begin{array}{l}\text { ICT is a supplement } \\
\text { to counseling. }\end{array}$ & $\begin{array}{l}20 \text { dollars per } \\
\text { assessment/raffle } \\
25 \text { dollars for } \\
\text { giving feedback }\end{array}$ \\
\hline [26] & $\begin{array}{l}\text { No problem } \\
\text { with } \\
\text { adherence. } \\
\text { Text messages } \\
\text { used to avoid } \\
\text { lack of } \\
\text { adherence }\end{array}$ & Not mentioned & Modified ITT approach & $\begin{array}{l}\text { Text messages, Being } \\
\text { Healthy4Baby, Facebook, } \\
\text { Website, Phone calls }\end{array}$ & $\begin{array}{l}\text { ICT is a supplement } \\
\text { to counseling. }\end{array}$ & $\begin{array}{l}100 \% \text { attendance }= \\
120 \text { dollars voucher } \\
\text { for time/travel }\end{array}$ \\
\hline [27] & Yes & Not mentioned & Yes & $\begin{array}{l}\text { Smart Loss Application, } \\
\text { SmartPhone, Body trace } \\
\text { scale, FitBit Zip } \\
\text { accelerometer (Bluetooth), } \\
\text { Phone, E-mail, Text mes- } \\
\text { sages, Sense wear } \\
\text { armband. }\end{array}$ & $\begin{array}{l}\text { ICT is a supplement } \\
\text { to counseling. }\end{array}$ & Not mentioned \\
\hline [28] & $\begin{array}{l}\text { No problem } \\
\text { with } \\
\text { adherence, but } \\
\text { it is discussed } \\
\text { that over time } \\
\text { it could be an } \\
\text { issue }\end{array}$ & $\begin{array}{l}\text { No, but the authors have } \\
\text { made one that has been } \\
\text { approved }\end{array}$ & Half fulfilled & $\begin{array}{l}\text { Video game, Nintendo } \\
\text { Wii, CD, Game, Wii } \\
\text { console, email }\end{array}$ & ICT stands alone. & Not mentioned \\
\hline [29] & $\begin{array}{l}\text { No problem } \\
\text { with } \\
\text { adherence }\end{array}$ & Not mentioned & Not fulfilled & $\begin{array}{l}\text { Pedometer, Text } \\
\text { messages, Phone calls }\end{array}$ & $\begin{array}{l}\text { ICT is a supplement } \\
\text { to counseling. }\end{array}$ & Not mentioned \\
\hline$[30]$ & $\begin{array}{l}\text { Not } \\
\text { mentioned }\end{array}$ & $\begin{array}{l}\text { No, but the authors have } \\
\text { made one that has been } \\
\text { approved }\end{array}$ & Yes & $\begin{array}{l}\text { Phone calls, } \\
\text { accelerometer, website }\end{array}$ & $\begin{array}{l}\text { ICT is a supplement } \\
\text { to counseling. }\end{array}$ & $\begin{array}{l}60 \text { dollar gift card } \\
\text { for participation }\end{array}$ \\
\hline [31] & $\begin{array}{l}\text { Not } \\
\text { mentioned }\end{array}$ & $\begin{array}{l}\text { No, but the authors have } \\
\text { made one that has been } \\
\text { approved }\end{array}$ & Not fulfilled & $\begin{array}{l}\text { Email account, } \\
\text { MyPyramidPlanner, }\end{array}$ & $\begin{array}{l}\text { ICT is a supplement } \\
\text { to counseling. }\end{array}$ & Not mentioned \\
\hline
\end{tabular}


a modified ITT strategy [28], which was unclear with respect to the risk of bias, and two studies did not apply any ITT $[29,31]$. Accordingly, their outcome data was unclear. Five of the studies addressed that adherence may decline over time [19, 25-28]. One study divided the intervention group post hoc into low, medium, and high adherence groups, due to a large variance in adherence. Among these, only the group with high adherence $(n=5)$ showed a significant difference in weight loss between the control group and intervention group $(-3.6$ to $1.6 \mathrm{~kg}$ versus $1.8-0.9 \mathrm{~kg} ; p=0.005)$ [27]. The post hoc analysis may however have an impact on the power of the sample size, and results should be considered with caution. Finally, one study noted a positive correlation between adherence and weight loss in the intervention group [19]. A financial reward was given for participation in half of the studies $[19,25,26,30]$. The participants were given between \$US 20 per assessment and the opportunity to take part in a raffle of \$US 25 , when completing a task [25], to \$US 120 for full participation [26].

The present review shows mixed results with respect to blinding. While the authors of one study claimed to follow the guidelines for blinding of participants and personnel [19], four studies only partially fulfilled the criteria $[25,26$, $29,30]$, and three of the studies did not mention blinding of participants and personnel [27, 28, 31]. When assessing blinding of outcome, the authors of two studies declared that they followed the guidelines [19, 30], one study had some degree of blinding [25], while five studies did not mention blinding of outcome assessment [26-29, 31]. All studies suggested low risk of bias with respect to "random sequence," "selective reporting," and "other bias." Five studies were assessed as having a low risk of bias for "allocation concealment" [19, 25, 29-31], while three studies suggested a high risk of bias [26-28]. Four studies had registered their trial in Clinical.trials.gov [19, 26, 27, 30], and one in ISRCTN. registry [28], while three studies recorded that the trials had been approved by a Review Board [26, 28, 31].

The present study was carried out to identify interventions that were effective with respect to weight loss, with the purpose of using these results in a further analysis. The interventions can be divided into categories according to their primary ICT component which were (1) Internet-based interventions, (2) text messages, (3) pedometer/accelerometer, (4) gaming, and (5) mobile application. Table 3 gives an overview of the categories in each intervention. The categories are described in detail below.

\section{1) Internet-based interventions}

MyPyramid Menu Planner [31], Fit Moms/Mamas Activas [19], and The Na Mikimiki intervention [30] examined the effect of an Internet-based intervention. Participants in MyPyramid Menu Planner [31] were given a customized account, where each participant entered dietary intake and physical activity three times each week. Both the participant and a dietician could access the account. Face-to-face counseling was used to introduce the account, and for counseling each week during the intervention period. In Fit Moms/Mamas Activas [19], participants received computerized feedback, text messages, face-to-face group meetings once a month at a clinic, and a weight and physical tracker. The participants also received access to a website, a web diary, and instructional videos. Participants in The Na Mikimiki intervention [30] were given access to a website and telephone counseling, where motivational techniques to overcome barriers and set future goals were used. The website contained tailored information about physical activity and newsletters. The intervention was based on Resnicow's framework for creating culturally sensitive interventions [32].

MyPyramid Planner and Fit Moms/Mamas Activas both showed a significant change in weight loss between the intervention group and the control group. In My Pyramid Planner, the difference in weight loss was $4.2 \mathrm{~kg}$ $(p<0.03)$ [31]. In Fit Moms/Mamas Activas, the difference was $2.1 \mathrm{~kg}$ at 6 months $(p<0.001)$ and $2.3 \mathrm{~kg}$ at 12 months $(p<0.001)[19]$.

Table 3 Overview of ICT-based categories in the eight interventions

\begin{tabular}{lllll}
\hline Reference & $\begin{array}{l}\text { Internet based } \\
\text { intervention }\end{array}$ & $\begin{array}{l}\text { Text messages (SMS [short message } \\
\text { system]) }\end{array}$ & $\begin{array}{l}\text { Pedometer/ } \\
\text { accelerometer }\end{array}$ & $\begin{array}{l}\text { Gaming } \\
\text { Mobile } \\
\text { application }\end{array}$ \\
\hline Phelan et al. [19] & $X$ & $X$ & $X$ & $X$ \\
Herring et al. [25] & & $X$ & $X$ & $X$ \\
Herring et al. [26] & $X$ & $X$ & $X$ \\
Gilmore et al. [27] & $X$ & $X$ & \\
Tripette et al. [28] & & $X$ & & \\
Maturi et al. [29] & & & \\
Albright et al. [30] & $X$ & & \\
Colleran and Lovelady & $X$ & & & \\
[31] & & & & \\
\hline
\end{tabular}


The Na Mikimiki intervention [30] used MVPA as a proxy to weight loss. This study also showed a significant difference in self-reported MVPA, between the intervention group and the control group, with an average of 44 to $246 \mathrm{~min} /$ week versus 46 to $146 \mathrm{~min} /$ week respectively $(p=0.027)$. Women with two or more children had a significantly increased MVPA compared to women with only one child, and the increase was greater in the intervention group compared to the control group $(p=0.016)$. Participants with low MVPA below the medium at baseline demonstrated a greater increase in MVPA compared to those with MVPA above the medium $(p=0.053)$, but without statistically significance at the $5 \%$ level.

\section{2) Text messages (SMS [short message system])}

All eight interventions included in the systematic review contained phone calls and/or text messages and/or emails as reminders, to give feedback, information, motivation, counseling, or to allow participants to ask questions. Most of the text messages and phone calls were tailored to the need of each participant. Text messages were the main component in two of the interventions: "The Healthy4Baby" and "Being Healthy for Baby" $[25,26]$, both of which are based on an intervention with daily text messages tailored to behavioral goals and reminders about returning information on calorie intake and physical activity. Facebook posts with video and links to websites were sent to participants, and each participant in the intervention group received weekly or monthly phone calls by a health coach, a digital scale for self-weighing, and a pedometer. Only the Healthy4Baby intervention showed a significant difference in weight loss between the intervention group and the control group after 14 weeks, with a weight difference equivalent to $(3.2 \mathrm{~kg} ; p=0.04)$, while Being Healthy for Baby intervention only showed a significant difference in the number of participants who were at, or below, their early pregnancy weights at 6 months postpartum (56\% versus 29\%; $p=0.04$ ), but not 12 months postpartum ( $41 \%$ versus $38 \%$; $p=0.83$ ).

\section{3) Pedometer/accelerometer}

The study by Maturi et al. is a physical activity intervention, based on a pedometer recording daily steps [29]. A counseling session at baseline, weekly reminders by text message, a phone call every second week, and a pamphlet after 8 weeks supported the intervention. After 12 weeks, a significant difference between the intervention group and the control group was found in physical activity and energy expenditure per week (4394 versus 1651 calories; $p<0.001)$ together with a significant difference in weight loss $(66.8 \mathrm{~kg}$ pre- and $64.7 \mathrm{~kg}$ post-intervention; $p=0.001$ ) compared to the control group $(63.9 \mathrm{~kg}$ pre- and $63.9 \mathrm{~kg}$ post-control; $p=0.001$ ). Five of the other studies included in the systematic review equipped the participants with an accelerometer or pedometer to measure physical activity as a part of the intervention (during the intervention period) [19, 25-27, 30].

\section{4) Gaming}

The Active Video Games (AVG) intervention [28] was based on the Nintendo Wii game. Each participant in the AVG group was provided with the game, a Wii console, and all necessary equipment. Participants were recommended to play the AVG for 30 min each day during the intervention period. No further recommendations were given. A significant difference in weight loss between the intervention group and the control group was found after 40 days $(-2.2 \pm 0.9 \mathrm{~kg}$ versus $-5 \pm 0.7 \mathrm{~kg}, p<$ $0.001)$. However, three of the fourteen participants in the intervention group complained about injuries from the use of the game. The follow-up period for the Nintendo Wii was only 40 days. None of the other interventions employed gaming elements in their interventions.

\section{5) Mobile application}

The SmartLoss application was given to the intervention group called "E-Moms," which is one form of individualized intervention with continuous surveillance [27]. The intervention consisted of a mobile application and a clinician dashboard, which made it possible for the clinician to monitor all E-Moms simultaneously, and potentially increase adherence to the intervention, and customize counseling. Based on weight development, each participant received instructions (SmartTips) on how to adjust calorie intake and set new goals for behavioral changes. The intervention also included an accelerometer, and a fictitious new "mom" called "Mia" who was going through a weight loss journey. A significant difference in weight loss was only present among the high adherence users in the intervention group (-3.6 \pm $1.6 \mathrm{~kg}$ versus $1.8 \pm 0.9 \mathrm{~kg} ; p=0.005)$. However, this group consisted of only five participants.

\section{Discussion}

The overall results show that ICT-based interventions, to some degree, support weight loss among postpartum women, which is also concluded by an existing review on e-health interventions for pregnant and postpartum women [20]. The studies included were pragmatic and were aimed to represent daily practice, compared to explanatory studies [33]. Pragmatic studies are at risk of being influenced by external conditions, as they are less controlled compared to explanatory studies. Individuals 
who volunteer to participate in a pragmatic study are often healthier, and/or better educated, and consequently some of the potential users may not be present in the studies, which may bias the generalizability.

The use of a narrative methodology contains limitations with respect to statistical analysis and has been criticized for being too narrow [34]. However, the methodology contains the strength that it can demonstrate not only what works, but also why and how it works. Heterogeneity between the studies is a limitation, as there is a wide variation between the included studies, with respect to the intervention, the setting, population, sample size, adherence to the intervention, follow-up period, blinding of participants and personnel, and blinding of outcome assessment. In addition, what is defined as standard care provided to both the intervention and control groups varies between studies. The differences make it difficult to compare the studies directly. However, the results demonstrate possible approaches to weight loss among postpartum women. Five of the studies had a relatively short follow-up period, which made the results uncertain, as participants, over time, may have lost interest in the intervention, which lowers the effect of the intervention. One of the studies with a long follow-up period only showed a significant change after 6 months, but not at 12 months [26]. In addition, the majority of the studies used a small sample size of 18 to 66 participants, which can be associated with increased uncertainty of the measured effect.

The contexts, in which the interventions were tested, may have had an impact on the results and limited external validity, as both the setting and the characteristics of the individuals in the samples may vary between countries. Statistical health data from the Organisation for Economic Co-operation and Development (OECD) also indicated a difference in lifestyle with respect to food consumption between countries [35]. Some of the studies included considered minority groups rather than the general population. However, a particular intervention targeted at a limited population may be beneficial to this specific group of people. Six of the studies were conducted in the USA, and thus, the overall results are found in a US context, but these do not necessarily present an image of how it works in the rest of the world. However, they demonstrate what can work in a US setting. All of the studies conducted in the USA used ICT as a supplement to counseling, and all had some kind of interaction between care provider or coach and the postpartum women. In addition, most of these studies did show a significant change, though mainly in the short run and among those with a high adherence to the interventions.

The financial reward can be seen as an extrinsic motivation for participants to take part in the study and so may improve adherence. The costs of providing a financial reward should therefore be evaluated as a part of the intervention. With the exception of The Nintendo Wii intervention [28], all the included studies contained a coach or healthcare provider to assist the participants by phone, text message, and/or face-to-face meetings. The intervention MyPyramidPlanner had a research assistant to travel to the women's homes up to three times a week to assist with childcare, facilitate the exercises, and have a weekly face-to-face talk about dietary intake [31]. Accordingly, the ICT-part of the interventions can be seen as a supplement to personal counseling, and personalized counseling is important for achieving weight loss goals [36]. However, the Nintendo Wii also showed a significant change in weight loss, so ICT interventions without counseling may be successful by using gaming.

Seven of the studies are unclear about blinding or the extent of blinding in the study and implies a risk of bias [25-31]. However, it has to be recognized that blinding is not always possible, as it is conceivable that participants know they are part of a study, and thus the validity of the results are weakened. The present study focuses solely on RCTs, so we have excluded results from studies using other methods.

Previous systematic reviews suggest that IT interventions can support weight reduction among postpartum women and suggest that the successful components of an intervention are personalized communication and frequent interaction with the intervention [20,37]. The present study indicates that a financial reward or gaming elements are also useful components, though further research on this area is required. The present study also includes additional studies compared to those included in the previous systematic reviews. Future studies should use longer follow-up periods, larger sample sizes, and methods to increase adherence to the interventions through counseling, feedback, rewards, and potentially also gaming elements [37].

\section{Conclusion}

The results from this study show that ICT-based interventions can assist weight loss. The main features of studies that demonstrated a significant change in weight contained elements of feedback, personal coaching, and frequent interaction with the intervention, gaming elements, or a financial reward. Significant change in weight loss appeals to motivation through the fun of gaming and may improve adherence (but replication is needed in more studies). Hence, future trials should take these features into account. It must be taken into account that only two of the studies had more than 100 observations, and only three studies had follow-up periods that were equal to or over a year. Thus, in the planning of future studies, one should carefully consider larger sample sizes, and longer follow-up periods. 


\section{Supplementary information}

Supplementary information accompanies this paper at https://doi.org/10. 1186/s13643-019-1186-2.

Additional file 1. Search string.

\section{Abbreviations}

GDM: Gestational Diabetes Mellitus; GWG: Gestational Weight Gain; ICT: Information and communication technology; IOM: Institute of Medicine; OECD: Organisation for Economic Co-operation and Development; RCT: Randomized Controlled Trial; T2DM: Type 2 diabetes mellitus

\section{Acknowledgements}

The authors would like to thank librarians at the Library at the University of Southern Denmark for advice on electronic search.

\section{Authors' contributions}

PKC has performed all steps of the research. MMS and the ED have assisted in designing the study. MMS joined in the data selection and in assessing the quality of each study selected. All co-authors have commented on drafts. All authors read and approved the final manuscript.

\section{Funding}

The review was funded by University College Lillebaelt, and Odense University Hospital

\section{Availability of data and materials}

Not applicable

\section{Ethics approval and consent to participate}

Not applicable

\section{Consent for publication}

All authors have given their consent for publication.

\section{Competing interests}

The authors declare that they have no competing interests.

\section{Author details}

'Department of Public Health, University of Southern Denmark, Odense, Denmark. ${ }^{2}$ Centre for Innovative Medical Technology, Odense University Hospital, Odense, Denmark. ${ }^{3}$ Department of Multimedia and IT, University College Lillebaelt, Odense, Denmark. ${ }^{4}$ OPEN, University of Southern Denmark, Odense, Denmark. ${ }^{5}$ Department of Endocrinology, Odense University Hospital, Odense, Denmark. ${ }^{6}$ Steno Diabetes Center Odense, Odense University Hospital, Odense, Denmark. ${ }^{7}$ Department of Clinical Research, University of Southern Denmark, Odense, Denmark. ${ }^{8}$ Department of Gynecology and Obstetrics, Odense University Hospital, Odense, Denmark ${ }^{9}$ Division of Surgery, University College London, London, UK. ${ }^{10}$ Northwick Park Institute of Medical Research Campus, London, UK.

Received: 28 February 2019 Accepted: 5 October 2019

Published online: 16 December 2019

\section{References}

1. WHO: http://www.who.int/mediacentre/factsheets/fs311/en/ (retrieved March 6, 2018).

2. OECD 2018. Non-medical determinants of health: https://stats.oecd.org/ Index.aspx?DataSetCode=HEALTH_LVNG\&_ga=2.95713500.1972631344.154 7302212-922445386.1547302212\# (Retrieved January 8, 2019)

3. Arendas K, Qui Q, Gruslin A. Obesity in pregnancy: pre-conceptional to postpartum consequences. J Obstet Gynaecol Can. 2008;30(6):477-88.

4. Nohr EA, Vaeth M, Baker JL, Sørensen T, Olsen J, Rasmussen KM. Combined associations of pre pregnancy body mass index and gestational weight gain with the outcome of pregnancy. Am J Clin Nutr. 2008;88(6):1750-9.

5. Baz B, Riveline J, Gautier J. Endocrinology of pregnancy: Gestational diabetes mellitus: defiition, aetiological and clinical aspect. Eur J Endocrinol. 2015;174:R43-51

6. Lauenborg J, Hansen T, Jensen DM, Vestergaard H, Mølsted-Pedersen L, Hornnes $\mathrm{P}$, et al. Increasing incidence of diabetes after gestational diabetes: a long-term follow-up in a Danish population. Diabetes Care. 2004;27(5): 1194-9.

7. Wallace JM, Bhattacharyal S, Horgan GW. Weight change across the start of three consecutive pregnancies and the risk of maternal morbidity and SGA birth at the second and third pregnancy. PLOS ONE. 2017;12(6):e0179589.

8. Boegarts A, Van den Bergh BR, Ameye L, Witters I, Martens E, Timmerman D, et al. Interpregnancy weight change and risk for adverse perinatal outcome. Obstet Gynecol. 2013;122(5):999-1009.

9. Lipski LM, Strawderman MS, Olsen CM. Maternal weight change between 1 and 2 years postpartum: the importance of 1 year weight retention. Obesity. 2012;20(7):1496-502.

10. IOM (Institute of Medicine). Weight gain during, re-examining the guidelines. Washington DC: The National Academies Press; 2009. https:// www.ncbi.nlm.nih.gov/pubmed/20669500.

11. Vesco KK, Dietz PM, Rizzo J, Stevens VJ, Perrin NA, et al. Excessive gestational weight gain and postpartum weight retention among obese women. Obstet Gynecol. 2009;114(5):1069-75.

12. Mamun AA, Karinavala M, O'Callaghan MJ, Williams GM, Ajma JM, et al. Associations of excess weight gain during pregnancy with long-term maternal overweight and obesity: evidence from 21 y postpartum followup. Am J Clin Nutr. 2010:91(5):1336-41.

13. Jakiciek JM, Davis KK, Rogers RJ, King WC, Marcus MD, et al. Effect of wearable technology combined with a lifestyle intervention on long-term weight loss: the IDEA randomized clinical trial. JAMA. 2016;316(11):1161-71.

14. Tech Terms: https://techterms.com/definition/ict (Retrieved August 15, 2019)

15. Sayakhot $\mathrm{P}$, Carolan-Olah M. Internet use by pregnant women seeking pregnancy-related information: a systematic review. BMC Pregnancy Childbirth. 2016:28(16):65.

16. Statistics Denmark 2017: https://www.dst.dk/da/Statistik/emner/priser-ogforbrug/forbrug/elektronik-i-hjemmet (Retrieved April 17, 2018).

17. Rathbone AL. The use of mobile apps and SMS messaging as physical and mental health interventions: systematic review. J Med Internet Res. 2017; 19(8):e295.

18. Phelan S. Pregnancy: a "teachable moment" for weight control and obesity prevention. Am J Obstet Gynecol. 2010;202:135e1-8.

19. Phelan S, Hagobian T, Brannen A, Hatley KE, Schaffner A, Munoz-Christian K, et al. Effect of an Internet-based program on weight loss for low-income postpartum women. A Randomized Clinical Trial. JAMA. 2017:317(23):2381-91.

20. Sherifali D, Nerenberg KA, Wilson S, Sememiuk K, Usman M, Redman LM, et al. The effectiveness of eHealth technologies on weight management in pregnant and postpartum women: systematic review and metaanalysis. J Med Inter Res. 2017;19(10):e337.

21. Khan KS, Kunz R, Kleinen J, Antes G. Five steps to conducting a systematic review. J R Soc Med. 2003;96(3):118-21.

22. Moher D, Liberati A, Tetzlaff J, Altman DG, PRISMA Group. Preferred Reporting Items for Systematic Reviews and Meta-analysis: The PRISMA statement. Ann Int Med. 2009:151(4):264-9.

23. Khan K, Kunz R, Kleijnen J, Antes G. Systematic reviews to support evidencebased medicine. 2nd ed. London: CRC Press; Taylor \& Francis Group; 2011.

24. Higgins JP, Altman DG, Gøtzsche PC, Jüni P, Moher D, et al. The Cochrane Collaboration's tool for assessing risk of bias in randomised trials. Brit Med J. 2011;343:d5928

25. Herring SJ, Cruice JF, Bennett GG, Davey A, Foster GD. Using technology to promote postpartum weight loss in urban, low-income mothers: a pilot randomized controlled trial. J Nutr Educ Behav. 2014:46(6):610-5.

26. Herring SJ, Cruice JF, Bennett GG, Niesha DD, Wallen JJ, et al. Intervening during and after pregnancy to prevent weight retention among African American women. Prev Med Rep. 2017;7:119-23.

27. Gilmore LA, Klempel MC, Martin CK, Myers CA, Burton JH, Sutton EF, et al. Personalized mobile health intervention for health and weight loss in postpartum women receiving women, infants, and children benefit: a randomized controlled pilot study. J Womens Health. 2017;26(7):719-27.

28. Tripette J, Marakami H, Gando Y, Kawakami R, Sasaki A, Hanawa S, et al. Home-based active video games to promote weight loss during the postpartum period. Med Sci Sports Exerc. 2014;46(3):472-8.

29. Maturi MS, Afshary P, Abedi P. Effect of physical activity intervention based on a pedometer on physical activity level and anthropometric measures after childbirth: a randomized controlled trial. BMC Pregnancy Childbirth. 2011;11:103

30. Albright $C L$, Steffen AD, Wilkens LR, White KK, Novotny $R$, Nigg CR, et al. Efectiveness of a 12-month randomized clinical trial to increase physical 
activity in multiethnic postpartum women: results from Hawaii's Nā Mikimiki Project. Prev Med. 2014;69:214-23.

31. Colleran HL, Lovelady CA. Use of MyPyramid Menu Planner for moms in a weight-loss intervention during lactation. J Acad Nutr Diet. 2012;112(4):553-8

32. Resnicow K, Baranowski T, Ahluwalia JS, Braithwaite RL. Cultural sensitivity in public health: defined and demystified. Ethn Dis. 1999;9(1):10-21.

33. Schwarz D, Lellouch J. Explanatory and pragmatic attitudes in therapeutical trials. J Clin Epidomiol. 2009;62:499-505.

34. Snilstveit B, Oliver S, Vojtkova M. Narrative approaches to systematic review and synthesis of evidence for international development policy and practice. J Dev Effect. 2012;4(3):409-29.

35. OECD 2017 - https://stats.oecd.org/index.aspx?DataSetCode=HEALTH_STAT (Retrieved August 29, 2018)

36. Obino K, Pereira C, Caron-Lienert R. Coaching and barriers to weight loss: an integrative review. Diabetes Metab Syndr Obes. 2017;10:1-11.

37. Sieverink F, Kelders SM, van Gemert-Piinen JE. Clarifying the concept of adherence to eHealth technology: systematic review on when usage becomes adherence. J Med Inter Res. 2017;19(12):e402.

\section{Publisher's Note}

Springer Nature remains neutral with regard to jurisdictional claims in published maps and institutional affiliations.

Ready to submit your research? Choose BMC and benefit from:

- fast, convenient online submission

- thorough peer review by experienced researchers in your field

- rapid publication on acceptance

- support for research data, including large and complex data types

- gold Open Access which fosters wider collaboration and increased citations

- maximum visibility for your research: over $100 \mathrm{M}$ website views per year

At BMC, research is always in progress.

Learn more biomedcentral.com/submissions 